\title{
Comer e cozinhar nas feiras do Guará e da Torre de TV
}

\section{Eating and cooking at Feira do Guará and Feira da Torre de TV}

Juliana Rampim Florêncio ${ }^{1}$

Esta comunicação apresenta os resultados expostos no segundo capítulo de minha dissertação de mestrado, concluída em 2018 no programa de pós-graduação em História da Universidade de Brasília (UnB): Comere cozinhar: revelando tramas e práticas alimentares como possibilidades de representação e identidades nas feiras do Guará e da Torre de TV, em Brasília. O capítulo analisa as falas obtidas com o uso da História Oral - entrevistas realizadas com feirantes e frequentadores das duas feiras.

A comunicação tem a intenção, portanto, de descrever e analisar as representações e identidades encontradas nas entrevistas realizadas, a partir das práticas alimentares como patrimônio cultural nesses espaços.

Dentre os resultados obtidos, destaco a apresentação das representações de tipicidade, tradição e de identidades dos alimentos comercializados. É frequente nas falas dos entrevistados termos como "comida típica", especialmente na Feira da Torre. Ali, há várias bancas de comidas chamadas de típicas, como o acarajé baiano, o tacacá paraense, o pastel de queijo mineiro e o churrasco gaúcho. Os feirantes entrevistados buscam alcançar a legitimidade do típico e do tradicional de seus produtos de várias formas: na indumentária, nas placas e fotos afixadas às paredes, e nas próprias falas.

A partir das representações de identidades encontradas, dialogo, entre outros autores, com Eric Hobsbawm, Carlos Dória, Câmara Cascudo, Néstor Canclini, Stuart Hall e Norbert Elias. Utilizo os três primeiros para questionar as possibilidades de existência dos conceitos de tipicidade e tradição nas comidas ali preparadas. Ao considerar a alimentação como cultura, como Massimo Montanari, é possível perceber a complexidade das relações que a envolvem. Deste modo, as ideias elaboradas pelos três autores realçam as ressignificações simbólicas e a constante transformação pelas quais os pratos chamados de típicos passam, o que problematiza a ideia de pureza e originalidade intocada pretendida nas falas.

O acarajé, descrito nas entrevistas como "tipicamente" baiano, é objeto de destaque e maior análise no capítulo devido à presença marcante nas citações e às formas em que o encontrei sendo vendido: no prato - desconstruído e acompanhado de talheres - e na barca de sushi (na qual todas as partes que compõem o acarajé são servidas para serem montadas pelo comensal). $O$ artigo analisa também as fotografias que ilustram esses aspectos e corroboram a argumentação, feitas durante as entrevistas.

A pesquisa pretende contribuir para a historiografia da cidade de Brasília (não havia ainda estudos sobre as práticas alimentares forjadas nesses espaços sob a perspectiva do patrimônio cultural além do Inventário Nacional de Referências Culturais, INRC, documento analisado e criticado no primeiro capítulo da dissertação. Todavia, este parece falhar em seu objetivo - inventariar as referências culturais desses espaços), bem como para a história da alimentação brasileira em 
caráter local, dados os registros de falas, as imagens anexas e a análise das identidades e representações ali presentes.

Palavras-chave: alimentação; representação; identidade; patrimônio cultural; Brasília.

Keywords: food; representation; identity; cultural heritage; Brasília.

1 Doutoranda em História pelo Programa de Pós-Graduação da Universidade de Brasília. 